\title{
Does China-US Trade Have an Impact on Employment of the United States?
}

\author{
Zhaohui Bi \\ Business School, Nanjing Normal University, Nanjing, China \\ Email: bizhaohui2015@163.com
}

How to cite this paper: Bi, Z.H. (2017) Does China-US Trade Have an Impact on Employment of the United States? Technology and Investment, 8, 158-166. https://doi.org/10.4236/ti.2017.83014

Received: July 12, 2017

Accepted: August 6, 2017

Published: August 9, 2017

Copyright $\odot 2017$ by author and Scientific Research Publishing Inc. This work is licensed under the Creative Commons Attribution International License (CC BY 4.0).

http://creativecommons.org/licenses/by/4.0/

\section{(c) (i) Open Access}

\begin{abstract}
International trade's real impact on domestic employment has always been controversial. In the 2016 presidential election, Donald Trump strongly argued that China-US Trade had resulted in many unemployed since China's accession to the WTO. Does China-US trade have an impact on the United States employment, and how does it affect employment? This is the main issue discussed in this paper. In the first part, this paper briefly introduces the status of China-US trade and the United States employment. Then, the second part discusses whether China-US trade has an impact on employment in the US and how it affects employment, and mainly argues allocation costs and adjustment costs of trade shocks as well as other factors of high unemployment of the United States, such as technology. The third part will give some advice about the problem of unemployment in the United States. The final part is a conclusion.
\end{abstract}

\section{Keywords}

China-US Trade, Trade Shocks, Unemployment, Adjustment Costs, Technology

\section{Introduction}

International trade's real impact on domestic employment has always been controversial. Traditional economic theory holds that trade can improve the welfare of countries. With the developing of globalization and international trade, and developing countries' such as China's fast growth; some developed countries like the US face the problem of unemployment. In the 2016 presidential election, Donald Trump strongly opposed free trade, and he argued that China's accession to the WTO had resulted in the closure of more than 50,000 factories in the US and the unemployment of more than 10 million workers. He recommends a $45 \%$ tariff on all Chinese imports. Does China-US trade have an impact on the 
United States employment, and how does it affect employment? This is the main issue discussed in this paper.

\section{The Status of China-US Trade and Employment in the United States}

To analyze whether China-US trade affects the United States employment, one must first look at the status and trends of both trade and employment.

\subsection{The Status of China-US Trade}

From Figure 1, it is clear that the total volume of China-US trade is growing quickly, from $\$ 26.555$ dollars in 1991 to $\$ 597.473$ billion in 2016 , and the average annual growth rate was $23.07 \%$. US imports and exports to China both grew from 1991 to 2016. US imports from China rose from $\$ 20.276$ billion in 1991 to $\$ 481.718$ billion in 2016 , and the average annual growth rate was $23.52 \%$. US exports to China rose from $\$ 6.278$ billion in 1991 to $\$ 115.755$ billion in 2016, and the average annual growth rate was $21.45 \%$. As Figure 1 illustrates, comparing with the imports and exports in 2015, these figures in 2016 have declined. For the US, import growth was slightly higher than exports to China. As can be seen from the Figure 1, the US trade deficit with China has been basically maintained at more than 200 billion dollars, and shows a gradual growth.

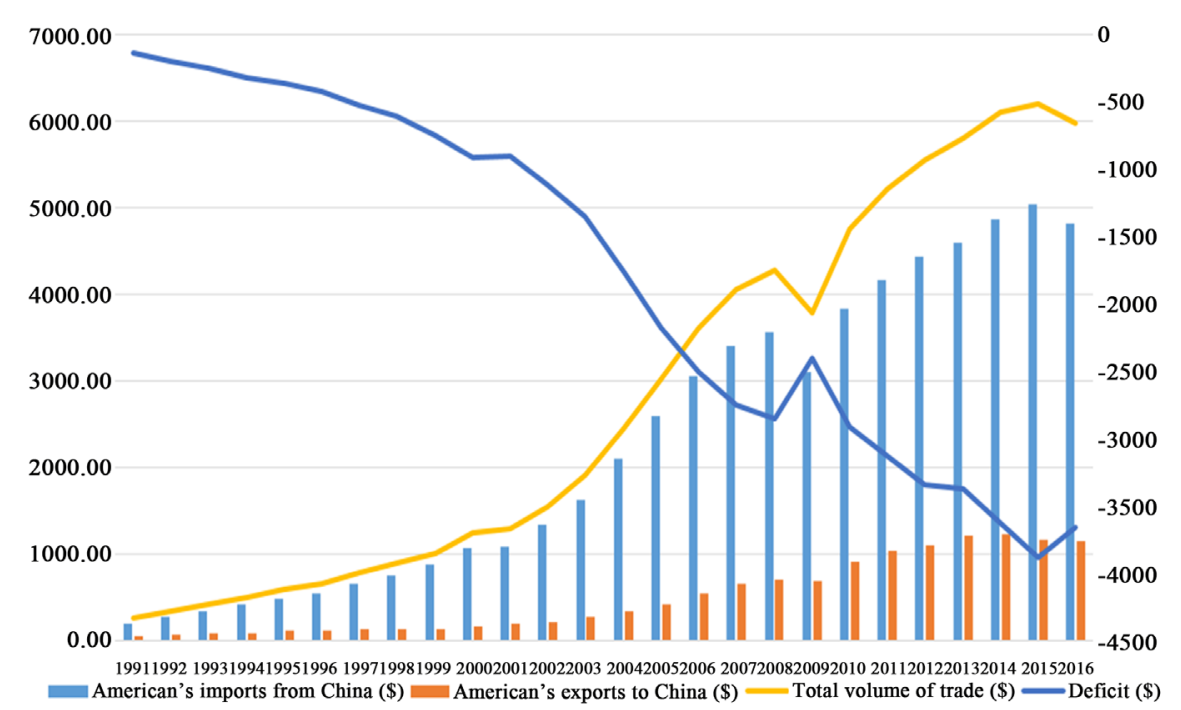

Figure 1. Trade value of China-US imports and exports (1991-2015). ${ }^{1}$

\subsection{The Status of the United States Employment}

In the 1980's, the United States had a relatively high level of employment until the boom of the late 1990's. Then the employment rate increased slowly, and reached a peak of $63.6 \%$ in 2000 , with the concurrent lowest unemployment rate of $4.1 \%$. After that, the employment rate fell sharply during the 2001 recession

${ }^{1}$ Source: UNTRADE,

https://comtrade.un.org/db/ce/ceSearch.aspx?it=Type+commodity+text+here\&rg=1\&r=842\&p=156 $\underline{\& y=r e c e n t \& p x=H S}$ 
and reached its lowest level in early 2003, before recovering through the 2007 economic expansion cycle. The recession caused by financial crisis from 2008 to 2009 caused another significant employment rate dive. In 2009, it had fallen to $58.3 \%$. The employment rate hits its nadir in 2011, with a rate of $57.3 \%$, with the peak unemployment rate of $9 \%$. From 2012 to the present, the employment rate has slowly been rising, but is still below $60 \%$. In the long run, the employment rate in the US dropped from $60.60 \%$ in 1991 to $58.5 \%$ in 2014 (Figure 2). We cannot, however, directly say that the change in employment rate is directly related to China-US trade because China-US trade has increased year by year while the employment rate has fluctuated. One of the reasons for this phenomenon is that employment is influenced by many factors, such as the macroeconomic situation, government policy (especially industry policy), the employment system, and so on.

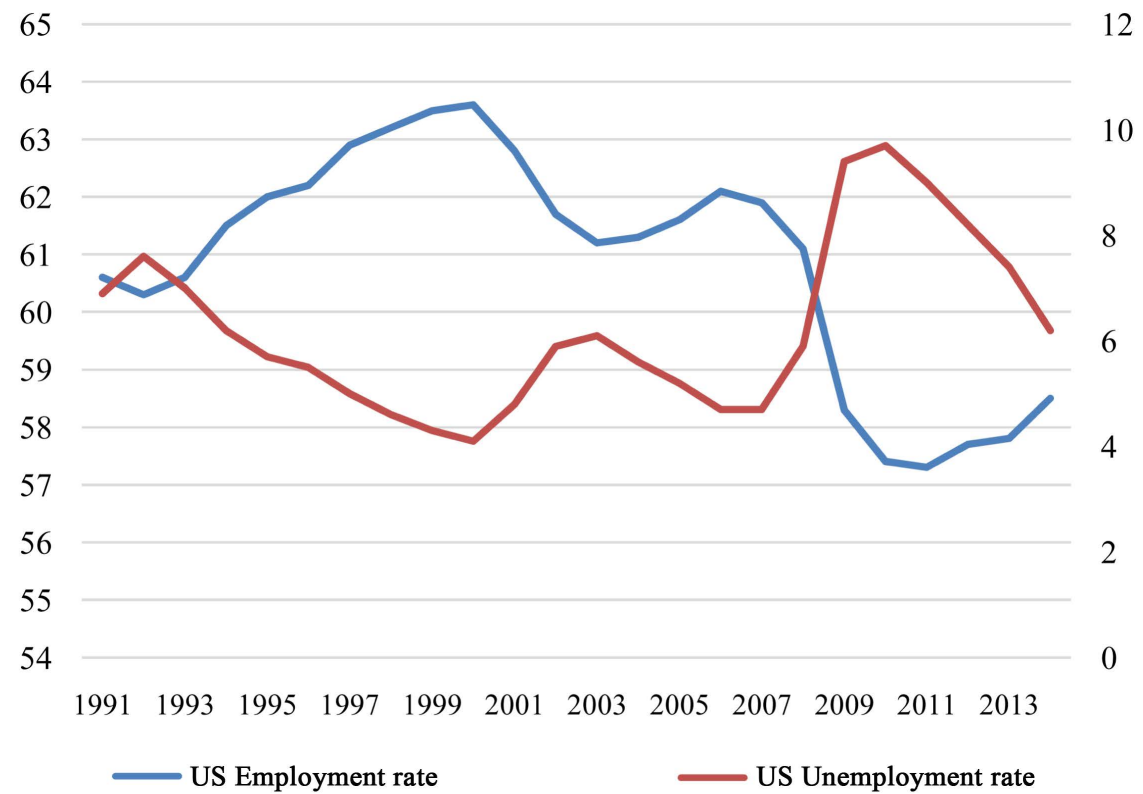

Figure 2. US employment and unemployment rate (1991-2014). ${ }^{2}$

Why, then, has Trump stressed the negative effects of globalization and trade? This is because, manufacturing employment in the United States is more directly affected by China-US trade than the overall employment rate. The share of US employment in manufacturing has been a downward trend since the end of WWII, peaking at $39.0 \%$ of US non-farm employment in 1944 and then falling to $8.6 \%$ in 2015 (Figure 3). Concerning Figure 1, it seems that the employment situation in the manufacturing sector is associated with a trade deficit between China and the United States. Simply relying on this data, however, gives an incorrect conclusion. During this period, technology was being constantly developed and it also had a large influence on manufacturing employment levels. The conclusions drawn by empirical method are also quite varied.

${ }^{2}$ Source: World Bank, http://data.worldbank.org/indicator/SL.EMP.TOTL.SP.ZS?locations=US; http://data.worldbank.org/indicator/SL.UEM.TOTL.ZS?locations=US 


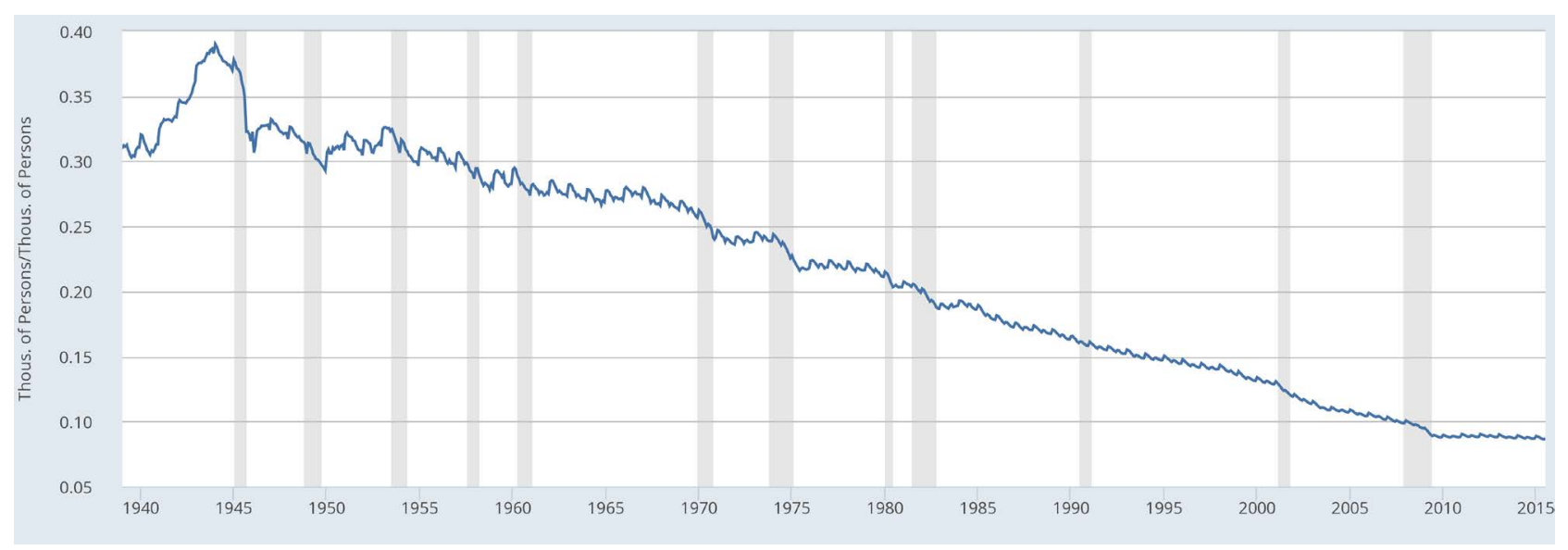

Figure 3. Manufacturing share of US non-farm employment (1939-2015). ${ }^{3}$

The empirical results of some scholars show that international trade is conducive to economic development and employment growth. Others' opinion is that international trade has a negative impact on employment. To this day, the real effect of international trade remains a controversial topic. Therefore, we need to further analyze the trade impact of employment mechanisms.

\section{How Does China-US Trade Effect Employment in the United States?}

Traditional economic theory makes the assumption that there is complete competence in goods and factors markets, and factors have enough mobility. Therefore, complete employment is a basic hypothesis of traditional international trade theory. Change in a good's price will cause domestic salaries to change accordingly, and employment will come to its complete status. In practice, however, the usual experiences in countries imply that international trade is in conflict with employment. There are several effects of trade on employment.

\subsection{Allocation Costs and Adjustment Costs Caused by Trade}

The traditional economics theory holds that trade will bring benefits to the country. In particular, trade can improve the level of domestic consumer welfare, by offering the same or better quality products at a lower price. However, trade can also incur significant costs, such as allocation costs and adjustment costs. Allocation costs mean that there is a difference in the benefits to be gained by different groups from international trade, in particular income inequality. In other words, wage differentials. Importing cheap, labor-intensive products from China could reduce demand for unskilled labor in the United States, damaging its benefits from trade. The trade-induced adjustment costs mainly include two aspects: first, some industries shrink domestically in real terms, creating costs for labor to find new jobs, living, or training skills for different jobs. Second, the displaced laborers are temporarily unable to find suitable jobs, and it creates the

${ }^{3}$ Source: FRED economic data, http://research.stlouisfed.org/fred2/graph/?g=1Gor 
cost of temporary unemployment.

General equilibrium trade theory suggests that the shock of sector demand to local employment effects could be unabridged because labor mobility forces and wage can dissipate these effects nationwide. After local manufacturing employment being affecting by trade shocks, cross-sector labor allocations would be affected rather than national labor market employment rates. However, the shocks of trade on the labor market may be amplified by a slow and incomplete adjustment due to adjustment costs, which have led to a significant decline in the employment rate in trade-affected local labor markets in the short term [1].

\subsection{Trade, Technology Advancement, and Employment}

Under open conditions, trade and technological progress are mutually reinforcing [2]. China-US trade has an important driving effect on the technological innovation of the United States. On the one hand, in trade with China, patent technology is not fully protected. Therefore, the United States advanced technology is imitated by China through trade. On the other hand, from China's imports of cheap industrial products and daily necessities, factors of production will transfer to advantageous industries from traditional industries, and it can promote the US industry to high-end development. Facing the pressure of imitation and China's labor-intensive export competition, US companies carry out defensive technological innovation, increasing $R \& D$ investment and innovation in the manufacturing industry in order to maintain its international competitiveness [3]. The effect of technology on employment is that the skill bias of technological progress drives some unskilled labor to be pushed out, which then leads to unemployment.

\subsection{Expansion Effects of Trade Shocks}

Negative shocks of trade to one industry can be transmitted to other industries because these industries are related [1]. Intermediate inputs maybe affect the spread of trade shocks nationwide. In the case of the tire trade, for example, once the increase in tire imports from China leads to a reduction in US tire production, US demand for steel fibers and synthetic rubber, which are intermediate products for tire production, may also decline, eventually spreading to the entire production chain. As a result, the negative impact of trade on an industry may be spread to other sectors, depending on the input-output relationship [4].

Acemoglu et al. [5] used input-output data to estimate the shocks to upstream imports for manufacturing and non-manufacturing industries in the United States. The results show that between 1999 and 2011, the trade shock-induced job losses were 985,000 manufacturing workers and 2 million workers in the economy as a whole, through direct and indirect input-output analysis. As a result, industrial linkages have increased the employment impact of trade shocks. The negative impact of trade on an industry may be spread to other sectors of the industry as a result of industrial linkages. 


\subsection{Does China-US Trade Have a Positive Impact on Employment in the United States?}

Scholars studying the manufacturing industry as a research object often focus on the analysis of US imports from China on the impact of employment, but rarely analyze the role of US exports to China. This may be due to a sharp decline in manufacturing employment in the United States since the 1990s, and for ChinaUS trade, imports from China are much larger than exports to China. Through the benefit from positive effects of exports on employment, the negative impact of imports on employment can be partially offset. International trade can facilitate the development of some sectors, such as service sectors, modern agriculture and high-end manufacturing, and the demand for labor in these sectors has been increasing. Then, the intrinsic link between manufacturing and non-manufacturing makes the employment of different sectors change in different directions. As a result, too much attention has been paid to the decline in manufacturing employment over the years, and people ignore the increase of employment in non-manufacturing sectors and the compensatory effects of export trade on employment.

Moreover, the expansion of the trade deficit, even indirectly, contributes to the transformation of industries and the increase in employment in information technology departments, as a result of the contribution of the expansion of imports to the "New Economy" in the United States since 1991. At the same time, a large number of cheap imports of overseas goods have saved the costs for importing nations, raised the level of consumption and brought greater good to consumers in those countries. Then it largely stimulated to the development of the United States "New Economy", which period the employment rate continued to increase.

Further, there is not a comparative advantage in labor-intensive general manufactured goods in the United States. If the United States tries to protect these industries, then it is actually in the protection of "backward" industries. The imports of a large number of manufactured goods has accelerated the phase-out and transformation of these relatively backward industries in the United States, thus promoting and accelerating the development of new high-tech industries in the United States. Therefore, the current China-US trade deficit situation is based on the comparative advantage of the international division of labor system. The China-US trade deficit provides external conditions for the United States to speed up industrial upgrading.

We also need to consider that employment is affected not only by imports and trade deficits, but are also directly influenced by the US domestic economy business cycle: the unemployment rate decreases during booms, and the unemployment rate rises as the economy falls into recession. Therefore, regardless of the specific industry, some workers may indeed be affected by the impact of imports, but on the whole, the US unemployment rate is not affected mainly and directly by the number of import shocks. 


\section{Some Advice about the Problem of Unemployment in the United States}

\subsection{Vocational Training for Laid-Off Workers}

On the surface, if the United States allows the impact of imports to go unallayed, the relative decline of backward industries will cause higher unemployment. Fortunately, workers can be properly trained to change jobs. First, low-tech traditional industries also have high-tech workers; they are relatively easy to transfer. Second, some low-skilled workers can be trained for high-tech work. Third, the high-tech industry itself has much low-tech work, and therefore the need for low-tech workers. Fourth, the traditional industries are not necessarily completely eliminated; many traditional industries can be used to transform the emerging technologies.

\subsection{The Relationship between Government Functions and Specific Interest Groups}

The 2016 presidential election shows the negative attitude people have about international trade and globalization, especially in areas where manufacturing is declining seriously. Many people think the United States needs strong protectionist policies, such as tariffs, to protect workers. However, opening and trade inevitably cause the adjustment of industrial structure and transformation. In fact, in the process of trade liberalization, there are winners and losers, but overall it provides net benefits to society. Implementation of strong trade protection would sacrifice the interests of trading partners, and thus their exports would also be difficult to stabilize and sustain, and ultimately reduce the level of social welfare. Furthermore, this policy is not conducive to technological progress. The US government should adopt a positive economic policy to carry out various forms of support to the transformation of re-employment training and subsidies through appropriate policies to encourage private investment and foster the international competitiveness of enterprises, promote the development of the company and other measures to expand employment opportunities. As long as the government carries out appropriate policies and develops new employment opportunities and resources, employment will be greatly improved, and trade protection requirements will be reduced accordingly.

\subsection{Take Advantage of the Positive Effect to Employment of Exports}

After the financial crisis, the US employment reaching its lowest point, with the unemployment rate reaching its highest. In order to improve the employment rate, the United States launched a program of doubling the United States exports, and China's import growth has become the key. From 2011 to today, the employment rate has been rising slowly. Through the input-output method of the SDA model, Xiao Jiehong [6] found that the employment effect of exports to the United States is increasing gradually, and there is great growth potential. From the breakdown of the industry point of view, in the past, the United States 
has mainly exported transportation and agricultural products to China, which are not labor-intensive industries. China's exports are mainly labor-intensive industries, where the pulling effect of employment is relatively large. Therefore, the United States can expand the exports scale and increase the diversification of ex- port products.

\section{Conclusion}

In sum, on the one hand, China-US trade may be a reason for the decline in US manufacturing employment because of the allocation costs and adjustment costs, technological progress effect, and expansion effects of trade shocks. At the same time, in terms of the overall status of employment in the United States, the factors affecting it are very large. Among them, employment and the macroeconomic situation, national policy (especially industrial policy) and technological progress are closely linked. Therefore, China-US trade is only one of these factors, and the effect of trade is not as obvious as other factors. On the other hand, the positive and negative effects of China-US trade are balanced. There is greater import competition in some manufacturing sectors in the United States, and at the same time there is also an expansion of exports in other manufacturing and other trade sectors (services and agriculture). China-US trade could lead to the redistribution of the United States workers from one industry to another, but not necessarily to their complete withdrawal from the labor force. If the redistribution mechanism operates, then when a local industry shrinks due to China's competition, other sectors within the same economic community should expand. Workers can move from the declining industries to those dominant industries. The problem is due to adjustment costs (as mentioned in Part 2.1). Workers need time to find new jobs; and these new jobs require different and superior skills. Also, these new jobs may be in different places. Labor mobility in the US also affects employment. Therefore, the United States government should try to provide more vocational training for laid-off workers and some preferential policies to help them find jobs in other places and industries. Expanding exports and increasing the diversification of export products also can help employment in the United States. In the process of globalization and trade liberalization, there are losers and winners, but overall it provides net benefits to the whole society. For solving the unemployment problem, the United States should focus more on the change of macroeconomic situation at home. Providing more training programs and support policies for the unemployed will be very helpful.

\section{Acknowledgements}

Sincere thanks to Professor Fuxin Jiang and Professor Paul-Armstrong Taylor for their professional guidance, and special thanks to Editorial Assistant Alice Yao for a rare attitude of high quality.

\section{References}

[1] Autor, D.H., Dorn, D. and Hanson, G.H. (2016) The China Shock: Learning from 
Labor Market Adjustment to Large Changes in Trade. Social Science Electronic Publishing, Rochester. https://doi.org/10.3386/w21906

[2] Wood, A. (1995) North-South Trade, Employment and Inequality: Changing fortunes in a Skill-Driven World. Clarendon Press, Wotton-under-Edge.

[3] Marin, D. and Verdier, T. (2003) Globalization and the New Enterprise. Journal of the European Economic Association, 1, 337-344. https://doi.org/10.1162/154247603322390973

[4] Pierce, J.R. and Schott, P.K. (2016) The Surprisingly Swift Decline of US Manufacturing Employment. American Economic Review, 106, 1632-1662. https://doi.org/10.1257/aer.20131578

[5] Acemoglu, D., Autor, D.H., Dorn, D., et al. (2014) Return of the Solow Paradox? It, Productivity, and Employment in U.S. Manufacturing. Social Science Electronic Publishing, 104, 394-399. https://doi.org/10.3386/w19837

[6] Xiao, J.H. (2013) An Analysis of the Impact of China-US Trade on Employment in the Two Countries. Journal of Statistics and Decision-Making, No. 12, 136-138.

\section{Scientific Research Publishing}

Submit or recommend next manuscript to SCIRP and we will provide best service for you:

Accepting pre-submission inquiries through Email, Facebook, LinkedIn, Twitter, etc. A wide selection of journals (inclusive of 9 subjects, more than 200 journals)

Providing 24-hour high-quality service

User-friendly online submission system

Fair and swift peer-review system

Efficient typesetting and proofreading procedure

Display of the result of downloads and visits, as well as the number of cited articles

Maximum dissemination of your research work

Submit your manuscript at: http://papersubmission.scirp.org/

Or contact ti@scirp.org 